\title{
Teachers' Appraisals In Multimodal Teachings Of Reading And Writing
}

\author{
Sri Mulatsih ${ }^{1}$, Issy Yuliasri ${ }^{2}$ \\ ${ }^{1}$ Postgraduate Program of Semarang State University \\ ${ }^{2}$ English Department of Semarang State University \\ \{1 sri.mulatsih@dsn.dinus.ac.id, ${ }^{2}$ issy.yuliasri@gmail.com\}
}

\begin{abstract}
Multimodal teaching is the one that applies several modes such as languages, gestures, pictures, technologies etc. Each mode in this teaching has its own meaning. Teachers' appraisals, as part of interpersonal meanings in teachers' utterances, are important in this teaching because they will support the teaching and learning process. This study is aimed at describing the appraisals given by the teachers in the classrooms and figuring out the kinds of appraising items realized in teachers' utterances. The steps used in collecting data are recording the teachers' utterances in Reading and Writing classes, transcribing the spoken data into the written ones. The frameworks proposed by Martin \& Rose (2003) and Martin \& White (2005) were used in analyzing the data. The steps used are identifying the teachers' appraisal given by the teachers, analyzing them based on engagement, attitude, and graduation; and then categorizing the types of appraising items used. The results showed that in term of engagement, monogloss are mostly found in the teachers' utterances. The source of the appraisals is mostly from teachers. Both teachers, in term of attitude, used mostly positive affect, judgement and appreciation. In graduation, both teachers used more focus than force. It means that both teachers tried to soften the language used in the teaching process. The kinds of appraising items used mostly by the teachers are in the form of attitudinal lexis and adjective phrases. It is caused by the fact that those types are easy to produce and more appropriate to be used in the teaching process compared to the other one.Abstract.
\end{abstract}

Keywords: Attitude, engagement. graduation, multimodal teaching, teachers' appraisals

\section{INTRODUCTION}

Reading and writing are two different English skills. Reading is a receptive skill, and writing is a productive one. . In teaching Reading and Writing, the teachers should not focus only in one mode. All teaching and learning in the classroom should involve a range of modes including speech, writing, gesture, gaze, body-posture, movement, and so on. In other words, teaching and learning in the classroom are multimodal [1]. It means that the teachers use several modes (source of meanings) such as languages (spoken and written ones), pictures, gestures, technology, etc. According to [2], every mode contributes meanings. Those meanings are ideational, interpersonal, and textual [3]. Ideational meaning is used to 
understand about things whether it is living or non - living and abstract or concrete things, about what is going on or in another word to know the process that is happening in the text and the around circumstances. Interpersonal meanings can be used to understand people's attitudes towards something whether they give information or goods services (commodity) and their speaking roles on a conversation. Textual meanings are about the organization of experiential and interpersonal meanings into a linear and coherent whole. In organizing any text to a coherent whole, one must keep the readers or listeners well informed about where the text is going by creating 'signposts'. According to [4], these signposts are called Theme, and the rests of the text or clause are called Rheme.

In teaching Reading and Writing, the teachers used utterances (spoken language) as one kind of modes. These utterances have important roles in supporting the teaching and learning processes in the classrooms. They also contribute meanings. As mentioned earlier, in Systmic Functional Linguistic theory, the meanings can be ideational, interpersonal and textual ones. Interpersonal meaning is developed into another theory to know how the readers are positioned in the text. The theory is called Appraisal. As stated in reference [5], "appraisal is concerned with evaluation: the kinds of attitudes that are negotiated in a text, the strength of the feelings involved and the ways in which values are sourced and readers aligned." They also mentioned that appraisal is a system of interpersonal meanings. The relation between appraisal and interpersonal meaning is their focus, both of them focus on the people's utterance and attitude. Appraisal is used to negotiate the social relation in human life by telling the feelings about people and things. There are three aspects in the appraisal system, they are engagement, attitude, and graduation.

Engagement is the source of the evaluations come from. It has two types aspects of attitudes sources, they are Monogloss (relating to the source of attitudes that come only from the author) and Heterogloss (relating to the source of attitudes that come from other than author). Attitude has to do with evaluating people's character and things. It consists of three aspects, they are affect, judgement, and appreciation. Affect is an attitude type which focuses on feeling expression toward something. According to [6] judgement is an attitude type which focuses on people's character. Appreciation is an attitude type which focuses on appreciation things. Graduation is the gradable system of how strong we express our feelings toward something. It consists of two types of resources, there are force and focus. Force is used on "turning the volume up and down"[5]. Focus about sharpening and softening meaning on evaluating people and things.

According to [6], the appraising items found in the appraisals can be in the form of attitudinal lexis, epithet, mental process, grammatical items, modality clause, metaphor, behavioural process, adjective phrase, relational process, modal adjunct, and minor clause. Appraisal theory can be used to analyze all types of evaluation. In multimodal teaching of Reading and Writing, teachers can also give evaluation towards the materials, the students, or even the media they use.

There are several studies discussing appraisals system. One of them is the one conducted by [7]. It is about Evaluative Language as Portrayed in The Texas Chainsaw Massacre Movie Review by Roger Ebert: An Appraisal Analysis. The results showed the reviewer tends to use attitudinal lexis in his evaluation. The evaluations are mostly sourced from the reviewer himself. The reviewer tends to evaluate things more than people, and his evaluations are mostly to be negative toward the movie.

The difference between this study and the previous one lies in the context of the data. The previous one used the context of movie, while this study used classroom discourse, that is the utterances used by the teachers in teaching Reading and Writing. 


\section{METHODOLOGY}

Methodology is a well-arranged and well-prepared way to achieve a good result. In other words, it is a systematic working procedure to facilitate an activity in achieving a particular purpose. This methodology consists of research design, subject of the research, data collection procedures, and data analysis techniques.

\subsection{Design of the Study}

This research is a descriptive qualitative one. It is called descriptive because it describes systematically the facts and characters of a given population or area of interest factually and accurately [8]. Further they say that descriptive research is used in the literal sense of describing situations or events. In this case, this research describes teachers' appraisals in teaching Reading and Writing and types of appraising items they used..

\subsection{Subject of the Research}

The subjects of this research are the teachers of Reading and Writing classes. The data of this research are in the form of teachers' utterances used in the teaching processes.

\subsection{Data Collection Prosedures}

The procedures of data collection applied the following steps: recording the teachers' utterances in teaching Reading and Reading classes, and transcribing the utterances into the written data.

\subsection{Data Analysis Techniques}

After the data were collected, then they were analyzed. The techniques to analyze the data were based on the frameworks proposed by [5] and [6]. The steps to analyze the data are reading the data, segmenting the data into clauses containing appraising items, identifying the teachers' appraisals, classifying them into engagement, attitude, and graduation, and last is describing the types of appraising items used by the teachers.

\subsection{Procedure of the Research}

The procedures of this research cover the following activities: determining the topic to be discussed in this study, choosing appropriate frameworks used to analyze the data, collecting the data, analyzing them, and drawing conclusion

\section{FINDING AND DISCUSSION}

\subsection{Findings}

In parts, two things are explained. They are the appraisal system found in the teaching of Reading and Writing, and the second is the appraising items used by the teachers.

\subsubsection{The Teachers Appraisals Found in Reading and Writing Classes}

There are three appraisals systems found in Reading and Writing classes. They are engagement, attitude, and Graduation. 


\subsubsection{Engagement}

As mentioned earlier, engagement can be in the form of monogloss and heterogloss. The number of engagement performed by the teachers of Reading and Writing can be seen in table 1 .

Table 1. Engagement in Reading and Writing Classes

\begin{tabular}{cccccc}
\hline & $\begin{array}{c}\text { Appraisal } \\
\text { Systems }\end{array}$ & $\begin{array}{c}\text { Reading } \\
\text { Class }\end{array}$ & $\mathbf{\%}$ & $\begin{array}{c}\text { Writing } \\
\text { Class }\end{array}$ & $\%$ \\
\hline Engagement & Monogloss & 23 & 88 & 11 & 85 \\
& Heterogloss & 3 & 12 & 2 & 15 \\
\hline Total & 26 & 100 & 13 & 100 \\
\hline
\end{tabular}

Table 1 showed that in term of engagement, in Reading and Writing classes, the number of monogloss in more than the one of heterogloss. The teacher in Reading class used 23 monogloss and 3 heterogloss. In Writing class the teacher used 11 monogloss and 2 heterogloss. This evidence showed that the source of the appraisal is from the teachers themselves, not from others. The examples of engagement can be seen in the excerp 1-2.

\section{Excerpt. 1}

That is a good explanation. (taken from Writing class)

The appraisal is "That is a good explanation". The appraised item is the student's explanation in answering the teacher's question. The source of this appraisal is monogloss because it comes from the teacher, not from others.

\section{Excerpt 2.}

This is the easiest genre compared to the other genres. (taken from Reading class)

The appraising item is "the easiest genre", and the appraised item is the procedure text. This appraisal is considered as heterogloss because the source of the appraisal is not from the teacher but from the book.

\subsubsection{Attitude}

Appraisal systems of attitude is divided into three types, they are affect, judgement, and appreciation. Types of attitude used by the teachers of Reading and Writing can be seen in table 2 .

Table 2. Attitude in Reading and Writing Classes

\begin{tabular}{lcccccc}
\hline & $\begin{array}{c}\text { Appraisal } \\
\text { Systems }\end{array}$ & & $\begin{array}{c}\text { Reading } \\
\text { Class }\end{array}$ & $\%$ & $\begin{array}{c}\text { Writing } \\
\text { Class }\end{array}$ & $\%$ \\
\hline Attitude & Affect & + & 10 & 38 & 5 & 39 \\
& & - & - & - & - & - \\
& Judgement & + & 7 & 27 & 4 & 31 \\
& - & - & - & 2 & 15 \\
& Appreciation & + & 8 & 31 & 2 & 15 \\
& & - & 1 & 4 & - & - \\
\hline & Total & & 26 & 100 & 13 & 100 \\
\hline
\end{tabular}


Table 2 showed that positive affect is dominantly used by the teachers in teaching Reading and Writing. It means that the teachers give the positive feeling towards the students. Positive judgement also dominant in reading and Writing classes. Most of these evaluations are given to the students. Positive appreciations in teaching Reading and Writing are given to the materials and the students' answers. The examples of attitude can be seen in excerpt $3-5$.

\section{Excerpt 3.}

Can you show me the examples of the text. Wow. (taken from Reading class)

The appraising item is "wow". The appraised item is the student. The teacher showed her positive feeling that she was happy with the student who brought the good example of the text.

\section{Excerpt 4.}

You give me a nice smile. (taken from Writing class).

The appraising item is "You give me a nice smile". The appraised one is the student. The teacher gave the positive judgement to the student because of her nice smile.

\section{Excerpt 5.}

It is a very small text. (taken from reading class).

The appraisal item is "It is a small text". The appraised item is the text. The teacher gave this negative appreciation because the text brought by the student is very small.

\subsubsection{Graduation}

Graduation covers force and focus. Graduation used by the teachers in teaching Reading and Writing can be seen in table 3 .

Table 3. Graduation in Reading and Writing Classes

\begin{tabular}{cccccc}
\hline & $\begin{array}{c}\text { Appraisal } \\
\text { Systems }\end{array}$ & $\begin{array}{c}\text { Reading } \\
\text { Class }\end{array}$ & $\begin{array}{c}\text { Writing } \\
\text { Class }\end{array}$ & $\%$ \\
\hline Graduation & Force & 5 & 19 & 2 & 15 \\
& Focus & 21 & 81 & 11 & 85 \\
\hline & Total & 26 & 100 & 13 & 100 \\
\hline
\end{tabular}

Table 3 revealed that the number of focus is more than the one of force. It means both teachers in Reading and Writing classes tried to soften their utterances rather than itensify them. Forces here are only used to emphasize the importance of certain parts of the materials. The examples of graduation can be seen in excerpt 6-7.

\section{Excerpt 6.}

You have to use the right technical terms. (taken from Writing class)

The appraising item is You have to use the correct technical terms. The appraised item is the students. The teacher gave the students force in order to remind them to be more careful in using the technical term is prcedure text. 


\section{Excerpt 7.}

Well, it is very nice. (taken from Reading Class).

The appraising item is It is very nice. The appraised item is the example of text given by the student. This graduation is considered as focus because the teaacher tone down the appraising item to give the compliment to the student.

\subsubsection{Kinds of Appraising Item Used by the Teachers}

The kinds of appraising items used by the teachers in Reading and writing classes can be seen in table 4

Table 4. Kinds of Appraising items Used by the Tachers

\begin{tabular}{cccccc}
\hline No & $\begin{array}{c}\text { Types of Appraising } \\
\text { Items }\end{array}$ & $\begin{array}{c}\text { Reading } \\
\text { Class }\end{array}$ & $\mathbf{\%}$ & $\begin{array}{c}\text { Writing } \\
\text { Class }\end{array}$ & $\%$ \\
\hline 1 & Attitudinal lexis & 10 & 38 & 4 & 31 \\
2 & Epithet & 7 & 27 & 2 & 15 \\
3 & Modality clause & 2 & 8 & 2 & 15 \\
4 & Adjective phrase & 5 & 19 & 4 & 31 \\
5 & Minor clause & 2 & 8 & 1 & 8 \\
\hline & $\sum$ & 26 & 100 & 13 & 100 \\
\hline
\end{tabular}

Table 4 showed that the kinds of appraising items mostly used by the teachers are attitudinal lexis and adjective phrase. Minor clauses are also used by the teachers to give the affect toward the answer of the students. The examples of these kinds of appraising items can be seen in excerpt 8-10.

\section{Excerpt. 8.}

It has the most interesting features. (taken from reading class)

The appraising item "the most interesting features" is categorized as epithet since it is used to describe the quality of the person or thing. In this example it is used to qualify the thing, that is the name of certain product.

\section{Excerpt.9.}

Well, it is very nice. (taken from Reading class).

The appraising item "very nice" is categorized as adjective phrase because this group of words is used to qualify the thing.

\subsection{Discussion}

As mentioned in the previous part, the number of appraisals given by the teacher of Reading class is more than the one of the Writing class. This is caused by the fact that in teaching Reading, as a receptive skill, the teachers not only gave the explanation about the materials but also gave the exercises to the students in the form of questions. The teachers, then, gave the appraisals or the evaluations towards their answers. On the other hand, in writing class, as a productive skill, there were not many questions given to the students, but 
mostly gave the explanations and instruction to write texts. That's why the number of appraisals given by the teacher in writing class is not as many as the ones of Reading.

In term of engagement, both teachers of reading and Writing classes used monogloss more that heterogloss. Almost all of their appraisals were given by the teachers themselves, not from other sources. It happens because reading and writing are English skills, the way to teach doesn't need too many sources outside the materials.

In term of attitude, positive affect, judgement, and appreciation were mostly used by both teachers. These positive attitudes are expected to be able to make the classed become as comfortable as possible and also to motivate the students in order not to be frustrated and get bored easily. The negative attitudes given here are only used to as a reminder for the students to study more seriously and to be careful in doing the assignment or answering the questions.

The number of focus is more than the one of force. Focus, as one of graduation, was used by the teachers because they want to tone down the conditions in the classrooms to make the students study comfortably and peacefully.

The kinds of appraising items used mostly by both teachers are in the forms of attitudinal lexis. These attitudinal lexis are commonly used to give judgement or appreciation toward the students or the materials being discussed.

\section{CONCLUSION}

Based on the analysis, it can be concluded that in term of engagement, monogloss are mostly found in the teachers' utterances. The source of the appraisals is mostly from teachers. Both teachers, in term of attitude, used mostly positive affect, judgement and appreciation. In graduation, both teachers used more focus than force. It means that both teachers tried to soften the language used in the teaching process. The types of appraising items used mostly by the teachers are in the form of attitudinal lexis and adjective phrases. It is caused by the fact that those types are easy to produce and more appropriate to be used in the teaching process compared to the other ones. It is recommended that in the teaching and learning processes, teachers should give appraisals to the students in order to motivate students in attending the course in the classrooms.

\section{References}

[1] G. Kress, Multimodality: A Social Semiotic Approach in Contemporary Communication. London: Routledge, 2009.

[2] K. L. O'Halloran, Systemic functional-multimodal discourse analysis (SF-MDA): Constructing ideational meaning using language and visual imagery, vol. 7, no. 4. 2008.

[3] M. A. . Halliday, Introduction to Functional Grammar. London: Edward and Arnold, 1985.

[4] D. Butt, R. Fahey, S. Feez, S. Spinks, and C. Yallop, Using functional grammar: an explorer's guide. National Centre for English Language Teaching and Research, Macquarie University, 2000.

[5] J. R. and R. D. Martin, Working with Discourse. Newyork: Continuum, 2003.

[6] P. R. . Martin J.R and White, Language of Evaluation: Appraisal in English. Newyork: Palgrave Macmillan, 2005.

[7] E. Crystalia and S. Sunardi, "Evaluative Language as Portrayed in The Texas Chainsaw Massacre Movie Review by Roger Ebert: An Appraisal Analysis," E-Structural, vol. 1, no. 01, pp. 58-69, 2019.

[8] S. Isaac and W. B. Michael, Handbook in research and evaluation: a. San Diego, Calif: 
EdITS, 1995. 